\title{
A contribution for the limnological knowledge of basaltic knickzones
}

\author{
E. M. Brambilla ${ }^{*}$, A. M. C. Ruocco ${ }^{a}$ and M. G. Nogueira ${ }^{a}$ \\ ${ }^{a}$ Departamento de Zoologia, Instituto de Biociências de Botucatu, Universidade Estadual Paulista - UNESP, \\ Campus de Botucatu, Distrito de Rubião Júnior, s/n, CEP 18618-970, Botucatu, SP, Brazil \\ *e-mail: eduardo.brambilla@gmail.com
}

Received: December 2, 2016 - Accepted: December 20, 2016 - Distributed: May 31, 2018

(With 5 figures)

\begin{abstract}
The knickzones are defined as locally steep riverbed segments, such as a convex reach in a concave-up longitudinal profile. They are worldwide distributed and geologically well studied, but despite their distinctiveness as a particular kind of macrohabitat there is a notorious lack of ecological knowledge. In this context, this research proposal aims to provide a physical description, in terms of kind of habitats, and a limnological characterization of a basaltic knickzone. Information is based on a case study carried out in the Sapucaí-Mirim River, Southeast Brazil. Samplings were performed in three different habitats well represented in the knickzone (runs, riffles and pools) during rainy and dry conditions. A clear discrimination in terms of habitat type and seasonality was demonstrated through a principal component analysis. Pools exhibited higher amplitude of variation for most limnological parameters when compared to runs and riffles, probably due to a great influence of the internal metabolism (photosynthetic production and community respiration). Despite of their geological ancient formation and the little understanding of their ecological role, the knickzones are in imminent threat in several regions of the world by hydropower dams implementation. The lack of ecological information on knickzones is probably due to inherent access difficulties and how to compare the distinct kinds of habitats. Thereby, further studies should be encouraged.
\end{abstract}

Keywords: run, riffle, pool, river longitudinal profile, limnological variables.

\section{Uma contribuição para o conhecimento limnológico dos pedrais basálticos}

\section{Resumo}

Os pedrais são definidos como segmentos de rio com leito localmente íngreme, tais como um alcance convexo em um perfil longitudinal côncavo. Eles são mundialmente distribuídos e geologicamente bem estudados, mas apesar de sua distinção como um tipo particular de macrohabitat há uma notória falta de conhecimento ecológico. Neste contexto, a proposta desta pesquisa é fornecer uma descrição física, em termos de tipo de habitats, e uma caracterização limnológica de um pedral basáltico. A informação é baseada em um estudo de caso realizado no rio Sapucaí-Mirim, no Sudeste do Brasil. As amostragens foram realizadas em três diferentes habitats bem representados na zona de pedral (rápidos, corredeiras e poças) durante as condições chuvosa e seca. Uma clara discriminação em termos de tipo de habitat e sazonalidade foi demonstrada através de uma análise de componentes principais. As poças apresentaram maior amplitude de variação para a maioria dos parâmetros limnológicos quando comparadas aos rápidos e corredeiras, provavelmente devido a grande influência do metabolismo interno (produção fotossintética e respiração das comunidades). Apesar de sua formação geológica antiga e da pouca compreensão de seu papel ecológico, os pedrais estão em ameaça iminente em várias regiões do mundo pela implementação de barragens hidrelétricas. A falta de informações ecológicas sobre os pedrais é provavelmente devido às dificuldades inerentes de acesso e como comparar os tipos distintos de habitats. Assim, devem ser encorajados novos estudos.

Palavras-chave: rápido, corredeira, poça, perfil longitudinal do rio, variáveis limnológicas.

\section{Introduction}

Knickzones are defined as locally steep riverbed segments, such as a convex reach in a concave-up longitudinal profile. These particular river stretches are often characterized by changes in bed cover, channel geometry and erosion processes that are difficult to incorporate within a stream-power framework (Dibiase et al., 2014;
Hayakawa and Oguchi, 2009). The formative causes of knickzones include hydraulic forces, hydrological changes, climatic changes and volcanic activities. Knickzones are composed by different substrates, such as sedimentary, volcanic, plutonic and metamorphic rocks (Hayakawa and Oguchi, 2009). 
In case of knickzones composed by volcanic rocks it is remarkable the representativeness of the basaltic composition. In South America, they are commonly found in the Paraná River Basin. This is a geographically vast intracratonic basin, fully developed on continental crust and filled with sedimentary and volcanic rocks, whose ages range between the Silurian and the Cretaceous (Milani, 1997; Souza Filho and Stevaux, 2004).

These natural rocky platforms are propitious sites for the positioning of hydroelectric dam's axes, in terms of engineering strategy. Worldwide, electricity production increased by $72 \%$ between 1993 and 2010 and is expected to rise by an additional $56 \%$ by 2040 (The World Bank, 2014a). Thirty two countries including Brazil, Mozambique, Nepal, and Norway use hydropower to produce more than $80 \%$ of their electricity requirements (The World Bank, 2014b). In Brazil, there is the perspective of construction of hundreds of new hydropower plants (1871 projects in distinct stages of implementation - ANEEL, 2013), representing an imminent regional threat for this kind of habitat (locally named as "pedrais").

Despite the fact that knickzones are worldwide distributed and geologically well studied (Crosby and Whipple, 2006; Hayakawa and Oguchi, 2009; Dibiase et al., 2014; Lima and Binda, 2013), they are practically unknown environments in terms of ecological structure and limnological functioning. This lack of knowledge can be explained by the inherent difficulties to access this kind of environment, including total impossibility of safe navigation. The fact that is a mosaic of distinct habitats, including lotic and lentic ones, result in an additional methodological problem. The purpose of this research is to provide a physical description, in terms of habitats distinctiveness and a limnological characterization of a basaltic knickzone.

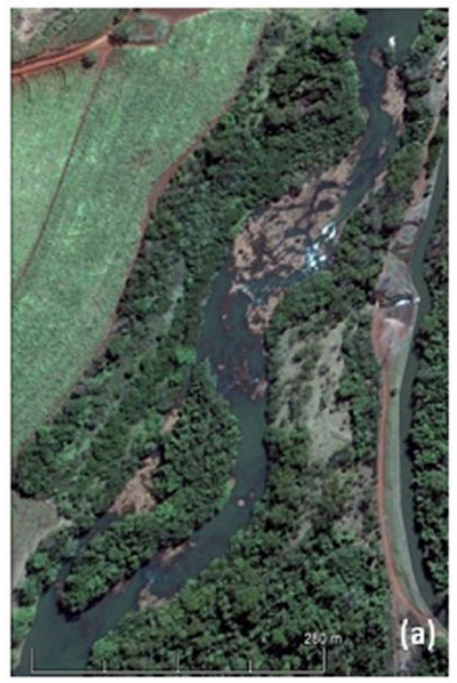

\section{Material and methods}

\subsection{Study area}

The studied knickzone (2034'34.1' S $47^{\circ} 47^{\prime}$ 06.5” W) is located in Sapucaí-Mirim River, a tributary of Grande River basin, border of São Paulo and Minas Gerais States, Brazil. Based on recent satellite images at least eight basaltic knickzones can be still be recognized in this middle-sized river.

In the selected kind of knickzone the immersed or exposed condition of the substrate is highly variable in terms of volume and level. Differences are mainly seasonal (summer-dry and winter-rainy periods) or can also occur in stochastic short-term periods (storms and dry spells events). When the river water level is high the substrate of knickzone is fully immersed (Figure 1b). When the rainfall stops the water level begins to decrease and consequently the degree of substrate exposition increases (Figure 1a). In the study it was considered two contrasting conditions: highly immersed (rainy condition) and highly exposed (dry condition).

\subsection{Sampling and analyses}

Samplings were performed in three different habitats - pools, runs and riffles, under dry and rainy conditions during three consecutive years (September/2012 - dry condition; May/2013 - rainy condition; June/2014 dry condition and December/2014 - rainy condition). Three runs, seven pools and six riffles were selected for the study (Appendix A). Riffles were sampled only in the dry condition, due to the access restriction during high flow periods. In case of the pools, four were connected with the river flow, and three were isolated, resulting in variations in their physical characteristics: volume of water, degree of connection with river flow, amount of

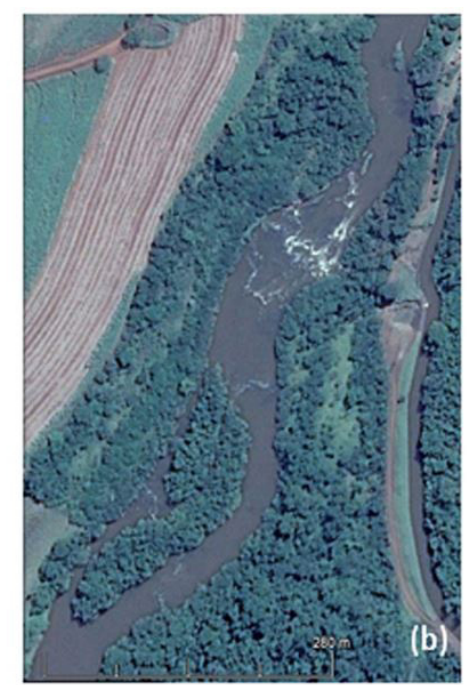

Figure 1. Study area - knickzone of the Sapucaí-Mirim River, Brazil, during dry (a) (July/2010) and flood condition (b) (May/2013). 
filamentous algae (visual observation) and the presence of terrestrial herbaceous vegetation (Table 1).

The maximum length, maximum width and maximum depth dimensions were measured with graduated tape and ruler, for pools volumes calculation. For riffles and runs, the water velocity was measured through the time displacement of a floating object and with a Flowatch current meter, depending on the sampling occasion.

A Spearman correlation analysis was performed between monthly accumulated rain precipitation and daily mean outflow per month for the definition of dry and rainy seasons. Previously, the normality of data was checked. Precipitation values for the period 2012, 2013, 2014 and 2015 were provided by the INMET (National Institute of Meteorology) nearest station (Franca municipality about $47 \mathrm{~km}$ ) and by the sugar cane processing plant named Alta Mogiana (station about $14 \mathrm{~km}$ ). Daily mean outflow was obtained from the energy company Duke Energy Brazil for the same period (data from Palmeiras small hydroelectric power plant).

Surface measurements of temperature, dissolved oxygen (DO), conductivity, oxide reduction potential (ORP), total dissolved solids (TDS) and $\mathrm{pH}$ were obtained using a daily calibrated Horiba probe (U-52). Simultaneously, water samples were collected for determination of total nitrogen and total phosphorus (Strickland and Parsons, 1960; Valderrama, 1981; Mackereth et al., 1989), total solids (TS) (Eaton et al., 2005), organic suspended solids (OSS), inorganic suspended solids (ISS), total suspended solids (TSS) (sensu Cole, 1979), and chlorophyll- $a$ (Golterman et al., 1978).

The sampling sites were arranged in seven groups: isolated pools in dry condition (PDI), connected pools in dry condition (PDC), isolated pools in rainy condition (PRI), connected pools in rainy condition (PRC), runs in dry condition $(\mathrm{RuD})$, runs in rainy condition (RuR) and riffles in dry condition (RiD). The mean values differences among the groups were tested by a one way ANOVA after the data transformation in $\log x+1$. When differences were detected, the Tukey test was used for significance analyses $(p<0.05)$. Previously, Kolmogorov Smirnov test was used to check for data normality. All tests were performed using StatisticaTM 7.0 software.

Data ordination and identification of temporal and spatial tendencies was performed using a principal components analysis (PCA) with data transformed in log $\mathrm{x}+1$ (except $\mathrm{pH}$ ) through PRIMER v6.0 software.

\section{Results}

The studied knickzone is physically characterized by the massive presence of a large rock outcrop, which originates a complex of habitats composed by riffles, runs and pools with distinct magnitudes (Figure 2a). Riffles are distributed discontinuously along the knickzone macrohabitat and are characterized by relatively narrow channels, with steep slopes and high turbulence, velocity and water flow (Figure 2b). Runs are continuous habitats, deeper than riffles, with lower turbulence and velocity (Figure 2c). Finally, the pools, such as the riffles, are heterogeneously distributed, with distinct degrees of connectivity with river flow. The pools exhibit low or no turbulence, the water exchanges tend to zero and deepness is highly variable (Figure 2d).

The fluctuation of rain precipitation and river flow during the studied period is showed in Figure 3. Both variables were positively correlated ( $r s=0.618 ; p<0.05$ ). The precipitation exhibited a well-marked seasonal pattern, with high volumes in summer and maximum peaks in December and January. Annual mean precipitation, for the three year period, was $1.454 \mathrm{~mm}$. Simultaneous daily values of outflow and rain precipitation along the rainy season - October 2014 to March 2015 are shown in Figure 4. A comparison between visits, satellite images and river flow suggest that this particular knickzone is totally under water when river flow values reach $90 \mathrm{~m}^{3} \mathrm{~s}^{-1}$. Between October 2014 and March 2015 the knickzone exhibited this condition during 15 days.

The amplitude of variation for all limnological measurements was higher in pools compared to riffles and runs, except for total phosphorus. Conversely, the runs were more conservative habitats, with lower variability.

Table 1. Physical characteristics of the seven pools shown in the dry and rainy condition in a knickzone of Sapucai Mirim River, River Grande basin SP / MG.

\begin{tabular}{|c|c|c|c|c|c|c|c|c|}
\hline \multirow{2}{*}{ HABITAT } & \multicolumn{2}{|c|}{ VOLUME } & \multicolumn{2}{|c|}{ CONNECTION } & \multicolumn{2}{|c|}{ ALGAE } & \multicolumn{2}{|c|}{$\begin{array}{c}\text { MARGINAL } \\
\text { VEGETATION }\end{array}$} \\
\hline & DRY & RAINY & DRY & RAINY & DRY & RAINY & DRY & RAINY \\
\hline $\mathrm{C1}$ & $* *$ & $* * *$ & $* *$ & $* * *$ & $* *$ & - & yes & yes \\
\hline $\mathrm{C} 2$ & $*$ & $* *$ & $* *$ & $* * *$ & $* *$ & - & no & yes \\
\hline C3 & $* * *$ & $* * *$ & $* * *$ & $* * *$ & $* *$ & - & no & no \\
\hline $\mathrm{C} 4$ & $* *$ & $* * *$ & $*$ & $* *$ & $* * *$ & - & no & no \\
\hline I1 & $*$ & $*$ & - & - & - & - & no & no \\
\hline I2 & $* * *$ & $* * *$ & - & - & $* *$ & - & no & no \\
\hline I3 & $*$ & $*$ & - & - & - & - & no & no \\
\hline
\end{tabular}

Volume: $*=<50 \mathrm{~m}^{3}, * *=50$ to $100 \mathrm{~m}^{3}, * * *=>100 \mathrm{~m}^{3}$; Connection: $*=$ low connection, $* *=$ medium connection, $* * *=$ high connection; Algae: $*$ low amount, $* *=$ medium amount, $* * *=$ high amount. 

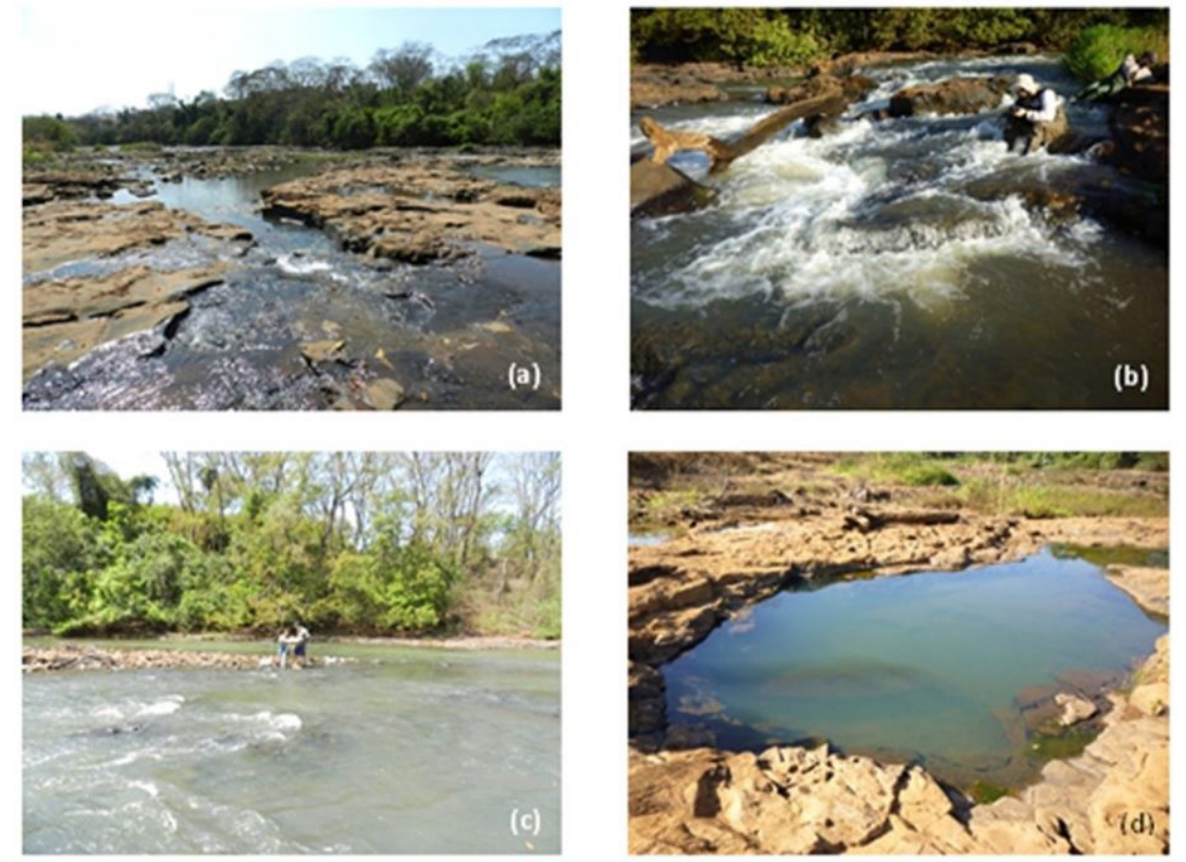

Figure 2. General view of a knickzone (a) formed by riffle (b), run (c) and pool (d) habitats in Sapucaí-Mirim River, Brazil.

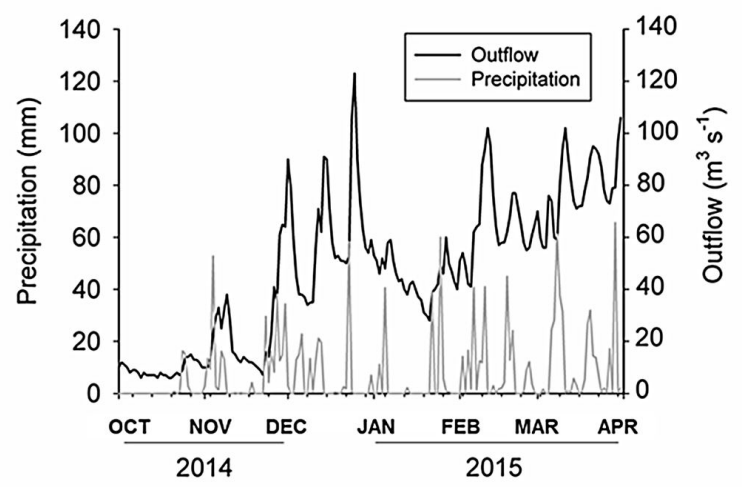

Figure 3. Precipitation in nearest meteorological station (Franca municipality - $47 \mathrm{~km}$ ) and outflow Bellow Palmeiras dam in Sapucaí-Mirim River, Brazil.

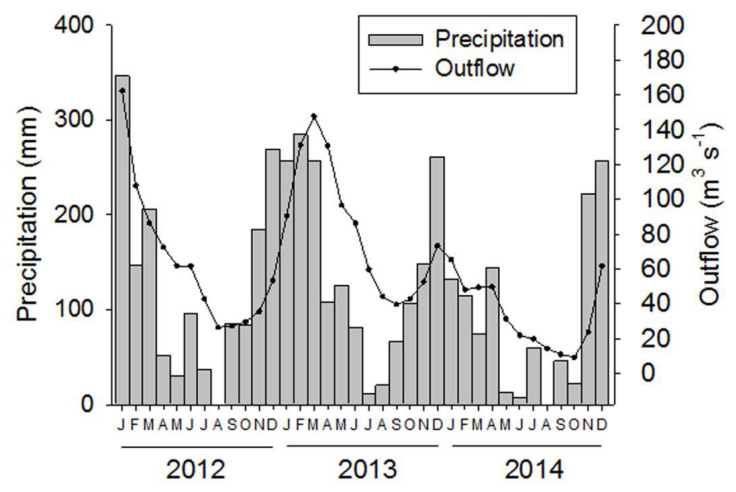

Figure 4. Daily values of rain precipitation (Alta Mogiana sugar cane plant station) and outflow (downstream Palmeiras dam) in Sapucaí-Mirim River, Brazil, along the rainy season (October 2014 to April 2015). 
Comparison among habitats data obtained in dry conditions (riffles were not accessed in rain conditions as previously mentioned) is presented in Table 2.

Most limnological measurements were statistically different among habitats $(p<0.05)$, except for total solids and total phosphorus (Table 3 ). Higher water temperature occurred in pools during the rainy condition and lower values were observed in the riffles. Connected pools during dry condition exhibited higher $\mathrm{pH}$ values opposite to runs in the rainy condition. Lower ORP values occurred in the connected pools during dry condition and higher in pools (connected and isolated) and runs during the rainy condition. Lower values of total dissolved solids occurred in pools and runs during the rainy condition. For total nitrogen higher values were observed in the dry condition for connected pools, riffles and runs. In terms of electric conductivity higher values were measured in runs and isolated pools in dry condition contrasting to pools (isolated and connected) and runs in rainy condition.

Isolated pools in dry condition were the least turbid habitat different from connected pools and runs in the rainy condition. Runs and connected pools in dry condition, as well as riffles (only sampled in dry condition), were the most oxygenated habitats. Higher concentrations of total suspended solids in the runs during rainy condition contrasted with low values in isolated pools, riffles and runs during dry period. Remarkable higher values of inorganic suspended solids were observed for pools and runs in the rainy condition. For organic suspended solids lower mean values occurred in riffles and runs and higher in connected pools, both during dry conditions. Chlorophyll- $a$ higher concentration was measured in isolated pools during dry condition and the lowest value in runs during the same period.

The PCA(Figure 5) explained $69.9 \%$ of data variability, considering the PC1 (54.4\%) and PC2 axis (15.5\%). The seasonal influence was clearly evidenced by the PC1 axis. Rainy condition was plotted on the negative side associated with high values of turbidity, total suspend solids, oxide reduction potential and temperature. The dry condition, on the positive side was positively associated with dissolved oxygen, $\mathrm{pH}$, conductivity, total dissolved solids and total nitrogen.

In the rainy condition the habitats distribution is more aggregated than in the dry period. Pools were grouped on the positive side of PC2 axis associated with high values of temperature and oxide reduction potential and runs were grouped on the negative side associated with high values of turbidity and total suspend solids. During the dry condition runs were grouped on the positive side of PC2 axis associated with high values of conductivity and total dissolved solids, riffles were grouped on the negative side associated to dissolved oxygen, $\mathrm{pH}$ and total nitrogen and pools are distributed randomly.

\section{Discussion}

The basaltic knickzones exhibit a unique complex structure due to the occurrence of distinctive kind of habitats: pools, riffles and runs of different magnitudes and degree of connectivity, distributed in relatively short river stretches. These environments are different when

Table 2. Environmental variables (maximum and minimum values) for each type of habitat in the dry condition.

\begin{tabular}{|c|c|c|c|}
\hline VARIABLES & RIFFLES (n=6) & RUNS (n=3) & POOLS $(n=7)$ \\
\hline Length (m) & $3.0-10.5$ & - & $3.2-31.7$ \\
\hline Width (m) & $1.8-3.5$ & - & $4.6-10.5$ \\
\hline Depth (m) & $0.1-0.55$ & - & $0.3-1.5$ \\
\hline Volume $\left(\mathrm{m}^{3}\right)$ & - & - & $5.9-200.3$ \\
\hline Water velocity $\left(\mathrm{m} \mathrm{s}^{-1}\right)$ & $0.4-2$ & $0.7-0.8$ & - \\
\hline Water temperature $\left({ }^{\circ} \mathrm{C}\right)$ & $17.9-19.3$ & $22.4-22.8$ & $19.4-24.2$ \\
\hline $\mathrm{pH}$ & 7.1-7.8 & $7.1-7.2$ & $7.0-9.1$ \\
\hline ORP $(\mathrm{mV})$ & $181.0-222.0$ & $264.0-272.0$ & $68.0-202.0$ \\
\hline Conductivity $\left(\mu \mathrm{S} \mathrm{cm}^{-1}\right)$ & $68.0-70.0$ & $94.0-94.0$ & $65.0-96.0$ \\
\hline Turbidity (NTU) & $8.6-269.0$ & $11.3-17.5$ & $1.9-37.5$ \\
\hline $\mathrm{DO}\left(\mathrm{mg} \mathrm{L}^{-1}\right)$ & $8.8-12.8$ & $8.8-10.0$ & $5.7-14.7$ \\
\hline DO $(\%)$ & $97.5-140.9$ & $104.3-117.8$ & $67.8-164.3$ \\
\hline TDS (mg L-1) & $44.0-46.0$ & $61.0-61.0$ & $42.0-63.0$ \\
\hline $\operatorname{TSS}\left(\mathrm{mg} \mathrm{L}^{-1}\right)$ & $2.9-7.2$ & $5.0-5.7$ & $1.2-8.1$ \\
\hline ISS $\left(\mathrm{mg} \mathrm{L}^{-1}\right)$ & $2.0-5.2$ & $3.4-4.1$ & $0.2-8.1$ \\
\hline OSS (mg L-1) & $1.0-2.0$ & $1.5-1.6$ & $1.0-6.0$ \\
\hline $\mathrm{TS}\left(\mathrm{mg} \mathrm{L}^{-1}\right)$ & $54.0-66.0$ & $64.0-70.0$ & $44.6-67.0$ \\
\hline Total phosphorous $\left(\mu \mathrm{g} \mathrm{L}^{-1}\right)$ & $13.2-74.1$ & $19.7-20.4$ & $14.1-59.2$ \\
\hline Total nitrogen $\left(\mu \mathrm{g} \mathrm{L}^{-1}\right)$ & $1649.0-2235.5$ & $1797.0-2176.0$ & $846.0-2055.0$ \\
\hline Chlorophyll- $a\left(\mu \mathrm{g} \mathrm{L}^{-1}\right)$ & $1.0-8.0$ & $0.5-0.5$ & $0.7-9.9$ \\
\hline
\end{tabular}

$\mathrm{n}=$ number of sampling habitats. 
Table 3. Mean and standard deviation for environmental variables measured in distinct habitats of a knickzone in SapucaíMirim River, Brazil.

\begin{tabular}{|c|c|c|c|c|c|c|c|}
\hline \multirow{2}{*}{ VARIABLES } & \multicolumn{4}{|c|}{ POOL } & \multirow{2}{*}{$\begin{array}{c}\text { RIFFLE } \\
\text { RiD }\end{array}$} & \multicolumn{2}{|c|}{ RUN } \\
\hline & PDI & PDC & PRI & PRC & & RuD & RuR \\
\hline \multirow[t]{2}{*}{ Water temperature $\left({ }^{\circ} \mathbf{C}\right)$} & $21.9^{a}$ & $20.9^{a}$ & $28.5^{\mathrm{b}}$ & $27.2^{\mathrm{b}}$ & $18.7^{\mathrm{c}}$ & $22.5^{\mathrm{a}}$ & $20.1^{\text {ac }}$ \\
\hline & $(1.5)$ & $(1.7)$ & $(2.2)$ & $(0.6)$ & $(0.5)$ & $(0.2)$ & $(0.0)$ \\
\hline \multirow[t]{2}{*}{ pH } & $7.3^{\mathrm{a}}$ & $8.5^{\mathrm{b}}$ & $7.4^{\mathrm{a}}$ & $7.2^{\mathrm{a}}$ & $7.4^{\mathrm{a}}$ & $7.2^{\mathrm{a}}$ & $6.0^{c}$ \\
\hline & $(0.3)$ & $(0.3)$ & $(0.1)$ & $(0.4)$ & $(0.3)$ & $(0.1)$ & $(0.1)$ \\
\hline \multirow[t]{2}{*}{ ORP (mV) } & $188.0^{c}$ & $94.5^{\mathrm{d}}$ & $319.7^{\mathrm{a}}$ & $322.8^{\mathrm{a}}$ & $206.8^{\mathrm{bc}}$ & $266.7^{\mathrm{ab}}$ & $325.7^{\mathrm{a}}$ \\
\hline & $(12.2)$ & $(23.6)$ & $(6.5)$ & $(14.4)$ & $(15.6)$ & $(4.6)$ & $(3.5)$ \\
\hline \multirow[t]{2}{*}{ Conductivity $\left(\mu \mathrm{S} \mathrm{cm}{ }^{-1}\right)$} & $82.7^{\mathrm{ab}}$ & $74.0^{\mathrm{a}}$ & $56.3^{\mathrm{c}}$ & $57.8^{\mathrm{c}}$ & $69.2^{\mathrm{a}}$ & $94.0^{\mathrm{b}}$ & $57.3^{\mathrm{c}}$ \\
\hline & $(15.9)$ & $(2.6)$ & $(1.5)$ & $(0.5)$ & $(0.8)$ & $(0.0)$ & $(0.6)$ \\
\hline \multirow[t]{2}{*}{ Turbidity (NTU) } & $6.8^{\mathrm{a}}$ & $18.4^{\mathrm{ab}}$ & $36.8^{\mathrm{ab}}$ & $52.6^{\mathrm{a}}$ & $55.5^{\mathrm{ab}}$ & $13.4^{\mathrm{ab}}$ & $48.8^{\mathrm{a}}$ \\
\hline & $(4.2)$ & (16.6) & $(14.5)$ & $(17.3)$ & $(104.6)$ & $(3.6)$ & $(1.3)$ \\
\hline \multirow[t]{2}{*}{ DO $\left(\mathrm{mg} \mathrm{L}^{-1}\right)$} & $6.6^{\mathrm{ab}}$ & $11.9^{c}$ & $6.5^{\mathrm{a}}$ & $7.0^{\mathrm{ab}}$ & $10.8^{c}$ & $9.3^{\mathrm{bc}}$ & $9.1^{\mathrm{abc}}$ \\
\hline & $(0.8)$ & $(2.7)$ & $(0.7)$ & $(0.3)$ & (1.9) & $(0.6)$ & $(0.3)$ \\
\hline \multirow[t]{2}{*}{$\operatorname{TDS}\left(\mathrm{mg} \mathrm{L}^{-1}\right)$} & $53.7^{\mathrm{ab}}$ & $48.0^{\mathrm{a}}$ & $36.7^{\mathrm{c}}$ & $37.8^{\mathrm{c}}$ & $45.0^{\mathrm{a}}$ & $61.0^{\mathrm{b}}$ & $37.3^{\mathrm{c}}$ \\
\hline & $(10.7)$ & (1.7) & $(0.6)$ & $(0.5)$ & $(0.6)$ & $(0.0)$ & $(0.6)$ \\
\hline \multirow[t]{2}{*}{ TSS $\left(m g \mathbf{L}^{-1}\right)$} & $4.1^{\mathrm{a}}$ & $11.8^{\mathrm{a}}$ & $18.6^{\mathrm{bc}}$ & $18.8^{\mathrm{c}}$ & $4.5^{\mathrm{a}}$ & $5.3^{\mathrm{ab}}$ & $25.1^{\mathrm{c}}$ \\
\hline & $(3.6)$ & (18.0) & $(10.8)$ & $(3.3)$ & $(1.6)$ & $(0.4)$ & $(3.6)$ \\
\hline \multirow[t]{2}{*}{ ISS (mg L L $\left.{ }^{-1}\right)$} & $1.0^{\mathrm{b}}$ & $1.5^{\mathrm{ab}}$ & $14.6^{\mathrm{cd}}$ & $15.2^{\mathrm{c}}$ & $3.1^{\mathrm{a}}$ & $3.7^{\text {ad }}$ & $19.5^{\mathrm{c}}$ \\
\hline & $(1.0)$ & $(0.4)$ & $(8.8)$ & $(2.5)$ & $(1.3)$ & $(0.4)$ & $(3.1)$ \\
\hline \multirow[t]{2}{*}{ OSS $\left(\mathrm{mg} \mathrm{L}^{-1}\right)$} & $3.1^{\text {abcde }}$ & $10.2^{\text {ace }}$ & $3.9^{\text {bce }}$ & $3.7^{\mathrm{bd}}$ & $1.4^{\mathrm{a}}$ & $1.6^{\text {acde }}$ & $5.6^{\mathrm{b}}$ \\
\hline & $(2.6)$ & $(17.8)$ & $(2.0)$ & $(0.8)$ & $(0.4)$ & $(0.1)$ & $(0.6)$ \\
\hline \multirow[t]{2}{*}{$\mathrm{TS}\left(\mathrm{mg} \mathrm{L^{-1 } )}\right.$} & $57.3^{\mathrm{a}}$ & $58.1^{\mathrm{a}}$ & $70.0^{\mathrm{a}}$ & $69.5^{\mathrm{a}}$ & $60.3^{a}$ & $67.0^{\mathrm{a}}$ & $66.0^{\mathrm{a}}$ \\
\hline & $(8.4)$ & $(9.3)$ & $(3.6)$ & $(4.2)$ & $(4.5)$ & $(3.0)$ & $(10.4)$ \\
\hline \multirow[t]{2}{*}{ Total phosphorous $\left(\mu \mathrm{g} \mathrm{L^{-1 } )}\right.$} & $31.3^{\mathrm{a}}$ & $18.8^{\mathrm{a}}$ & $26.7^{\mathrm{a}}$ & $23.2^{\mathrm{a}}$ & $27.2^{\mathrm{a}}$ & $20.0^{\mathrm{a}}$ & $17.0^{\mathrm{a}}$ \\
\hline & $(24.4)$ & $(2.8)$ & $(3.8)$ & $(8.0)$ & $(23.3)$ & $(0.4)$ & $(0.4)$ \\
\hline \multirow[t]{2}{*}{ Total nitrogen $\left(\mu \mathrm{g} \mathrm{L}^{-1}\right)$} & $1045.4^{\mathrm{a}}$ & $1803.4^{\mathrm{b}}$ & $1102.0^{\mathrm{a}}$ & $1170.6^{\mathrm{a}}$ & $1883.6^{\mathrm{b}}$ & $1950.0^{\mathrm{b}}$ & $588.6^{\mathrm{c}}$ \\
\hline & $(216.7)$ & $(236.3)$ & (199.2) & $(67.2)$ & $(234.5)$ & (199.8) & $(24.7)$ \\
\hline \multirow[t]{2}{*}{ Chlorophyll- $\boldsymbol{a}\left(\mu \mathrm{g} \mathrm{L}^{-1}\right)$} & $6.2^{\mathrm{a}}$ & $2.1^{\mathrm{ab}}$ & $2.1^{\mathrm{ab}}$ & $2.4^{\mathrm{ab}}$ & $3.1^{\mathrm{ab}}$ & $0.5^{\mathrm{b}}$ & $2.4^{\mathrm{ab}}$ \\
\hline & $(4.7)$ & $(2.1)$ & $(0.0)$ & $(1.2)$ & $(2.8)$ & $(0.0)$ & $(0.4)$ \\
\hline
\end{tabular}

PDI $=$ isolated pools in dry condition; PDC $=$ connected pools in dry condition; PRI $=$ isolated pools in rainy condition; $\mathrm{PRC}=$ connected pools in rainy condition; $\mathrm{RuD}=$ runs in dry condition; $\mathrm{RuR}=$ runs in rainy condition and $\mathrm{RiD}=$ riffles in dry condition. Superscript letters indicate statistical similarity (same letter) or difference (different letters) according to ANOVA test followed to Tukey test.

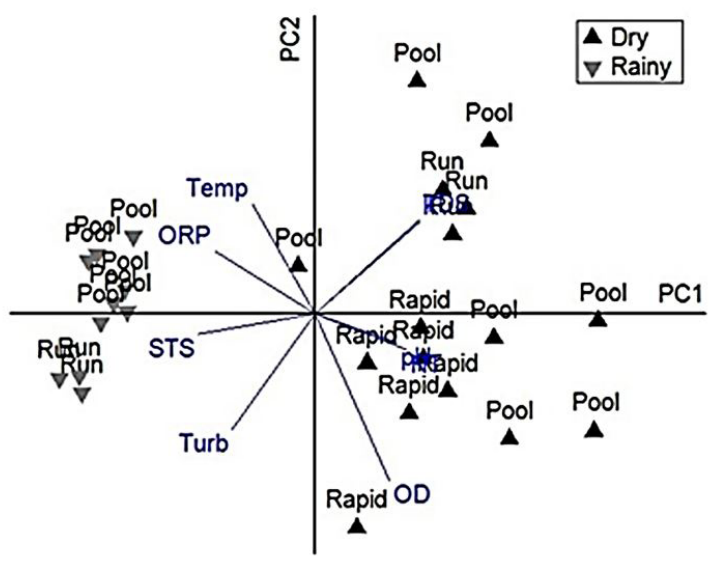

\begin{tabular}{|lcc|}
\hline Vanable & PCA 1 & PCA 2 \\
\hline Watentemperature & 0.227 & 0.397 \\
pH & 0.296 & -0.104 \\
ORP & 0.36 & 0.225 \\
Conductivty & 0.377 & 0.331 \\
Turbidity & 0.299 & -0.415 \\
DO & 0.269 & -0.602 \\
TDS & 0.375 & 0.338 \\
TSS & 0.421 & -0.073 \\
Total nitrogen & 0.332 & -0.13 \\
Engenvalues & 49 & 1.4 \\
\hline
\end{tabular}

Figure 5. Principal components analysis showing the distribution of the sampling sites in the rainy and dry condition, according to the limnological variables. 
compared with certain habitats such as streams and temporary pools. Riffles, runs and pools in stream ecosystems have a sequential distribution, in a continuous longitudinal organization (Allan, 1995). In case of inland temporary pools the location is generally apart from main water bodies, like river channels. Therefore, the possibilities for comparisons of our results are limited, basically restricted to the literature related to lateral river habitats and their interactions with the central channel.

Pools, runs and rapids distributed in mosaic have a distinct limnological dynamic among them. In terms of limnological variation, pools exhibit higher amplitude when compared to runs and riffles. This is explained by their particularities, such as small volume and low water renovation, but also by the considerable physical and biotic variability features (e.g. surface area, volume, degree of connection with adjacent running channels, presence of marginal vegetation, quantity of periphyton and fish biomass). Particularly in case of freshwater rock pools the highly variable environmental conditions in such small restricted water volumes, in addition to exposition of seasonal an erratic weather, require high stress tolerance of the biota, with adaptations for surviving the dry phase such as the production of resistant stages and active emigration followed by quick re-colonization (Jocque et al., 2010).

The seasonality also influence limnological characteristics in basaltic knickzones among the different microhabitats especially the alternation between dry and rainy periods, considering that river flow is promptly influenced by the rain precipitation. In the rainy period the similarity between habitats is expected to be higher because of considerable exchanges of water, sediment, nutrients, and organisms. The opposite occurs in the dry period when the homogenization process is less effective with a higher differentiation among habitats. This dynamics is evidenced when compared river channels and lateral ecosystems such as floodplains and lagoons (Domitrovic, 2003; Thomaz et al., 2007; Ferrareze et al., 2014).

In addition to the predictable seasonal changes, the basaltic knickzone habitats are exposed to erratic weather variation - random short-term events of intense precipitation and dry spell. Therefore, this environment exhibits a high disturb frequency. For more confined habitats (pools), certainly the hourly variation (nictemeral), especially in warmer periods plenty of sunshine, is also significant and would justify an additional investigation.

For characterization purposes, it is important to note that each limnological factor can vary in different ways for each particular habitat and time period. Higher temperatures were attained in pools during the rainy condition, coincident with the warmer period (late spring and summer), due to the smaller volume, low exchange rate with the main river flow and high influence of atmospheric conditions. The lowest temperature occurred in riffles, habitat with higher water flow/velocity, in the dry condition (autumn and late winter).

Pools, under dry condition, exhibited higher values of $\mathrm{pH}$, organic suspended solids and oxygen values. This is probably associated to the intense periphyton colonization, resulting in high photosynthesis rate and organic detritus accumulation. In some lateral river ecosystem and lagoons, the oxygen reduction in the rainy condition is associated due to the decomposition process of organic matter coming from the adjacent plain (Granado and Henry, 2012). This process may also occur in knickzone pools.

In general ORP is higher in the rainy season (pools and runs), probably due to the entrance of allochthonous material (high turbidity) from catchment, as already mentioned. An opposite tendency was observed for oxygen, which reached higher values during the dry condition in connected pools and riffles.

The lowest electrical conductivity of water (pools and runs), TDS (pools and runs) and total nitrogen (runs) in the rainy condition can be explained by the dilution effect. This pattern also occurs regionally in river lateral lagoons (Martins and Henry, 2004; Granado and Henry, 2012; Ferrareze et al., 2014).

Regarding turbidity, total and inorganic suspend solids, higher values occurred in rainy condition (mainly in connected pools and runs), while lower values (except for riffles due excessive turbulence) were seen in dry period (isolated pools). High loads of external material from the drainage basin are introduced into the river system during rains, especially in habitats with more intensive water exchange. Similar findings are reported for floodplains (Oliveira and Calheiros, 2000; Taniguchi et al., 2004, 2005).

The chlorophyll- $a$ distribution was contrasting between pools and runs. Higher values occurred in isolated pools (phytoplankton colonization) and lower in runs (washout effect), both during the dry condition. The increase of chlorophyll- $a$ during the dry period is a common pattern for large rivers and lakes of tropical/subtropical floodplains (Welcome, 1986; Garcia de Emiliani, 1990; Neiff, 1990), but this seems not to be applied for all knickzone habitats.

Our research shows that the studied basaltic knickzone exhibits a clear spatial limnological heterogeneity due to the presence of distinct habitats. This condition is even more accentuated during the dry season. Probably such structural and functional features are common traits for other kinds of knickzones, which could be demonstrated through further limnological studies.

\section{Acknowledgements}

We thanks Raoul Henry for useful suggestions in this manuscript; Marco Aurélio Pessotto, Diogo Freitas Souza and Danilo Augusto de Oliveira Naliato for help in field work activities and to CNPq for scholarship conceived for the first author.

\section{References}

AGÊNCIA NACIONAL DE ENERGIA ELÉTRICA - ANEEL [online], 2013 [viewed 25 July 2013]. Available from: http:www. aneel.gov.br/ 
ALLAN, D., 1995. Stream ecology: structure and functioning of running waters. Oxford: Chapman and Hall. 388 p.

COLE, G.A., 1979. Textbook of limnology. Saint Louis: Mosby Company. 426 p.

CROSBY, B.T. and WHIPPLE, K.X., 2006. Knickpoint initiation and distribution within fluvial networks: 236 waterfalls in the Waipaoa River, North Island, New Zealand. Geomorphology, vol. 82, no. 1-2, pp. 16-38. http://dx.doi.org/10.1016/j.geomorph.2005.08.023.

DIBIASE, R.A., WHIPPLE, K.X., LAMB, M.P. and HEIMSATH, A.M., 2014. The role of waterfalls and knickzones in controlling the style and pace of landscape adjustment in the western San Gabriel Mountains, California. Geological Society of America Bulletin, vol. 127, no. 3-4, pp. 539-559. http://dx.doi.org/10.1130/B31113.1.

DOMITROVIC, Y.Z., 2003. Effect of fluctuation in water level of phytoplankton development in three lakes of the Paraná River floodplain (Argentina). Hydrobiologia, vol. 510, no. 1-3, pp. 175193. http://dx.doi.org/10.1023/B:HYDR.0000008643.50105.4b.

EATON, A.D., CLESCERI, L.S., RICE, E.W. and GREENBERG, A.E., 2005. Standard methods for the examination of water and wastewater. Washington: American Public Health Association, American Water Works Association, Water Pollution Control Federation. 1368 p.

FERRAREZE, M.F., NOGUEIRA, M.G. and SARTORI, L.P., 2014. Limnology of a lateral lagoon system connected to a subtropical reservoir (SE, Brazil). Acta Scientiarum: Biological Sciences, vol. 36, pp. 197-207. http://dx.doi.org/10.4025/actascibiolsci. v36i2.21491.

GARCIA DE EMILIANI, M.O., 1990. Phytoplankton ecology of the middle Paraná River. Acta Limnologica Brasiliensia, vol. 3, pp. 391-417.

GOLTERMAN, H.L., CLYMO, R.S. and OHNSTAD, M.A., 1978. Methods for physical: chemical analysis of fresh waters. Oxford: Blackwell Scientific Publications. 213 p.

GRANADO, D.C. and HENRY, R., 2012. Changes in abiotic characteristics of water in the Paranapanema River and three lateral lagoons at mouth zone of the Jurumirim Reservoir during the flood period, São Paulo. Brazilian Latin American Journal of Aquatic Research, vol. 40, no. 1, pp. 79-89. http://dx.doi. org/10.3856/vol40-issue1-fulltext-8.

HAYAKAWA, Y.S. and OGUCHI, T., 2009. GIS analysis of fluvial knickzone distribution in Japanese mountain watersheds. Geomorphology, vol. 111, no. 1-2, pp. 27-37. http://dx.doi. org/10.1016/j.geomorph.2007.11.016.

JOCQUE, M., VANSCHOENWINKEL, B. and BRENDONCK, L., 2010. Freshwater rock pools: a review of habitat characteristics, faunal diversity and conservation value. Freshwater Biology, vol. 55, pp. 1587-1602.

LIMA, A.G. and BINDA, A.L., 2013. Lithologic and structural controls on fluvial knickzones in basalts of the Parana Basin, Brazil. Journal of South American Earth Sciences, vol. 48, pp. 262-270. http://dx.doi.org/10.1016/j.jsames.2013.10.004.

MACKERETH, F.J.H., HERON, J. and TALLING, F.J., 1989. Water analysis: some revised methods for limnologists. Kendall: Titus Wilson \& Sons. 124 p.
MARTINS, G.M. and HENRY, R., 2004. Composição e abundância do zooplâncton em três lagoas laterais ao rio Paranapanema na zona de sua desembocadura na represa de Jurumirim (São Paulo). In: S. CHELAPPA and J. Z. O. PASSAVANTE, eds. Ecologia aquática tropical. Natal: Serv Graf, pp. 53-72.

MILANI, E.J., 1997. Evolução tectono-estratigráfica da Bacia do Paraná e seu relacionamento com a geodinâmica fanerozóica do Gondwana sul-ocidental. Porto Alegre: Universidade Federal do Rio Grande do Sul, 255 p. PhD Thesis.

NEIFF, J.J., 1990. Aspect of primary productivity in the lower Paraná and Paraguay riverine system. Acta Limnologica Brasiliensia, vol. 3, pp. 77-113.

OLIVEIRA, M.D. and CALHEIROS, D.F., 2000. Flood pulse influence on phytoplankton communities of the south Pantanal floodplain. Hydrobiologia, vol. 427, no. 1, pp. 101-112. http:// dx.doi.org/10.1023/A:1003951930525.

SOUZA FILHO, E.E. and STEVAUX, J.C., 2004. Geology and Geomorphology of the Baía-Curutuba-Ivinheima River complex. In: S. M. THOMAZ, A. A. AGOSTINHO and N. S. HAHN, eds. The Upper Paraná River and its floodplain: physical aspects, ecology and conservation. Leiden: Blackhuys Publishers, pp. 1-30.

STRICKLAND, J.D. and PARSONS, T.R., 1960. A manual of sea water analysis. Bulletin Fisheries Research Board of Canada, vol. 125 , pp. 1-185.

TANIGUCHI, G.M., BICUDO, D.C. and SENNA, P.A.C., 2005. Gradiente litorâneo-limnético do fitoplâncton e ficoperifíton em uma lagoa da planície de inundação do rio Mogi-Guaçu. Brazilian Journal of Botany, vol. 28, no. 1, pp. 137-147. http://dx.doi. org/10.1590/S0100-84042005000100011.

TANIGUCHI, G.M.D., BICUDO, D.C. and SENNA, P.A.C., 2004. Abiotic variables in littoral-limnetic of an oxbow lake of Mogi-Guaçu River floodplain, southeastern. Brazilian Archives of Biology and Technology, vol. 47, no. 6, pp. 961-971. http:// dx.doi.org/10.1590/S1516-89132004000600016.

THE WORLD BANK, 2014a [viewed 8 October 2014] Electricity production $(\mathrm{kWh})$ [online]. Washington. Available from: http:// data.worldbank.org/indicator/EG.ELC.PROD.KH/

THE WORLD BANK, 2014b [viewed 8 October 2014] Electricity production from renewable sources, excluding hydroelectric ( $\mathrm{kWh}$ ) [online]. Washington. Available from: http://data.worldbank.org/ indicator/EG.ELC.RNWX.KH/

THOMAZ, S.M., BINI, L.M. and BOZELLI, R.L., 2007. Floods increase similarity among aquatic habitats in river-floodplain systems. Hydrobiologia, vol. 579, no. 1, pp. 1-13. http://dx.doi. org/10.1007/s10750-006-0285-y.

VALDERRAMA, J.G., 1981. The simultaneous analysis of total nitrogen and phosphorus in natural waters. Marine Chemistry, vol. 10, no. 2, pp. 109-122. http://dx.doi.org/10.1016/03044203(81)90027-X.

WELCOME, R.L., 1986. The Niger River system. In: B. R. DAVIES and K. F. WALKER, eds. The ecology of river systems. Dordrecht: Dr. W. Junk Publishers, pp. 9-23. 
Appendix A. Pictures of pools, runs and riffles sampled in the dry and rainy condition in a knickzone of Sapucai Mirim River, River Grande basin SP / MG.

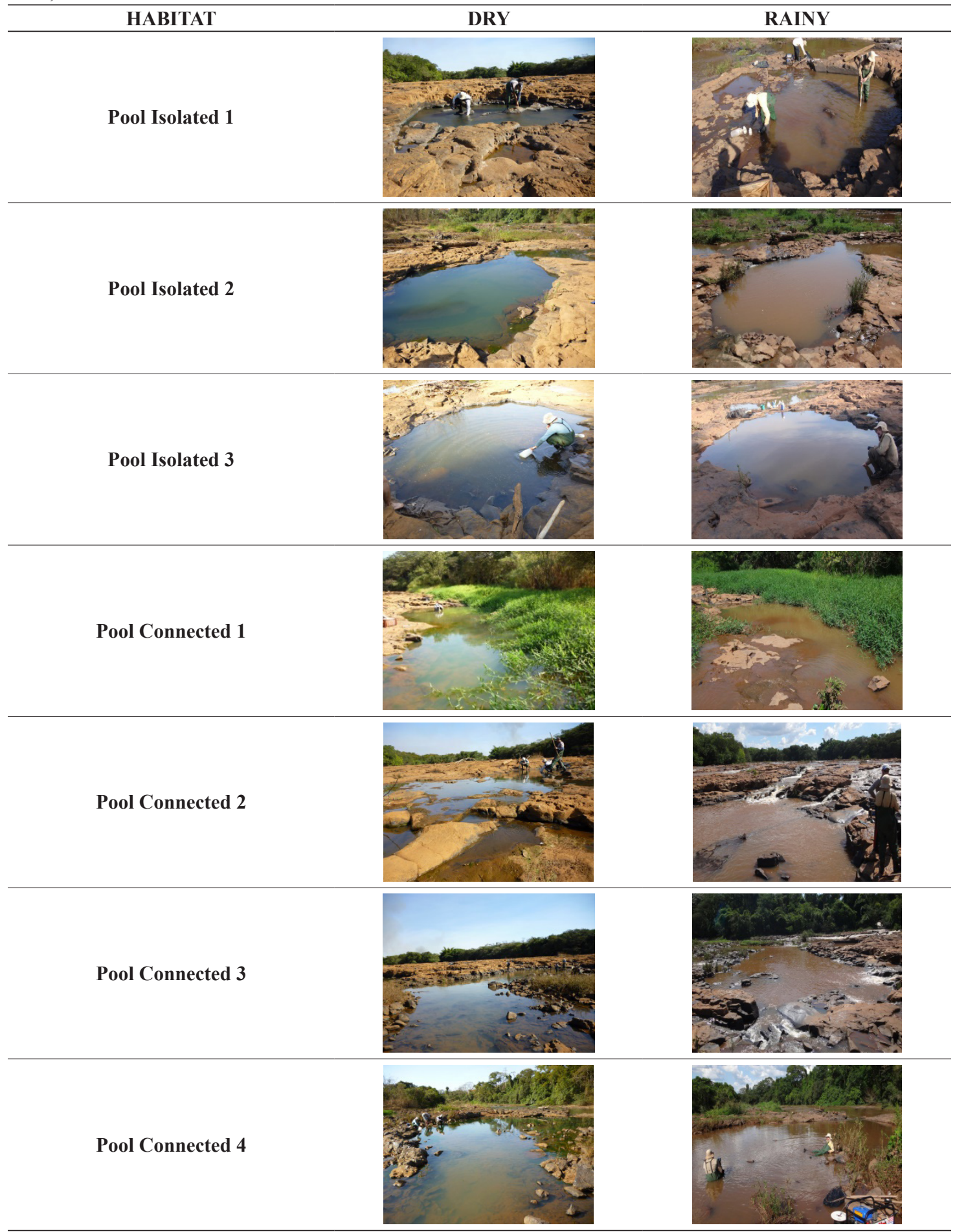


Appendix A. Continued...

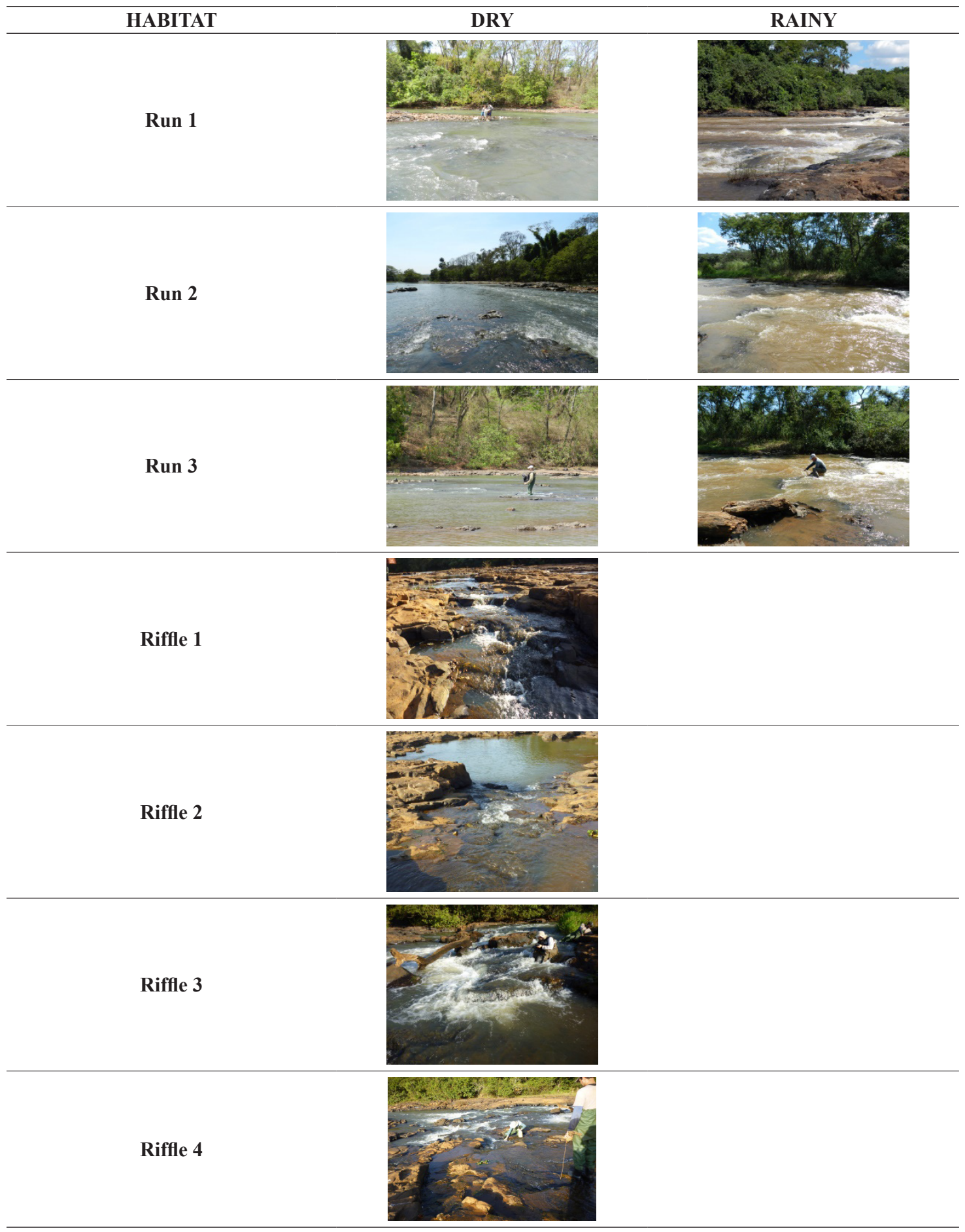


Appendix A. Continued...

\begin{tabular}{|c|c|c|}
\hline HABITAT & DRY & RAINY \\
\hline Riffle 5 & & \\
\hline Riffle 6 & & \\
\hline
\end{tabular}

